ISSN 0258-7122

Bangladesh J. Agril. Res. 34(4) : 673-681, December 2009

\title{
SCREENING OF WHEAT GERMPLASM FOR THEIR SUSCEPTIBILITY AGAINST DIFFERENT SEEDLING DISEASES
}

\author{
M. U. AHMED ${ }^{1}$, ABUL KHAIR ${ }^{2}$ AND I. H. MIAN ${ }^{3}$
}

\begin{abstract}
Fifteen wheat germplasm, namely BAW-1033, BAW-1045, BAW-1056, BAW1061, BAW-1064, BAW-1004, BAW-1008, BAW-1027, BAW-1035, Sonalika, Gourob, Protiva, Shatabdi, Sourov and Kanchan (check) were screened against different seedling diseases in two consecutive years under inoculated condition. Before sowing, the soils of the experimental field were inoculated with five fungal pathogens, namely Sclerotium rolfsii, Biplaris sorokiniana, Fusarium oxysporum, Pythium aphanidermatum, and Rhizoctonia solani,. Considering the lower percent of diseased seedling and higher vigour index, four wheat germplasrn, namely Shatabdi, BAW-1045, BAW-1004 and Protiva were selected as tolerant materials against seedling diseases.
\end{abstract}

Key Words : Screening, wheat germplasm, seedling diseases.

\section{Introduction}

Wheat is the second most important cereal crop of Bangladesh. The national average yield of wheat is 1.90 metric t/ha, which is considered lower as compared to many wheat growing countries of the world (Ahmed and Meisner, 1996).

Among the various factors responsible for low yield of wheat in Bangladesh, diseases play a vital role. Like other crops, wheat suffers from a number of seed and soil borne diseases. In Bangladesh, so far 20 different diseases have been recorded on wheat (Talukdar, 1974; Ahmed and Hossain, 1985; Ahmed, 1986; Alam et al., 1994; Ahmed, 1994). Of them, foot and root rot (Sclerotium rolfsii, Bipolaris sorokiniana, Fusarium oxysporum, Rhizoctonia solani and Pythium aphanidermatum), seedling blight (B. sorokiniana and Alternaria triticina), black point (B. sorokiniana, A. alternata), Bipolaris leaf blight (B. sorokiniana) and leaf rust (Puccinia recondita) are important diseases of wheat and cause appreciable yield loss every year.

Seedling diseases, such as foot and root rot and seedling blight that attack at seedling stages of crop directly reduce plant population as well as yield of wheat. Chattopadhay (1953) reported that within 15 days of germination in inoculated soil, seedling became infected and died gradually, there being some 50-60\%

\footnotetext{
${ }^{1}$ Ph.D. Fellow, Department of Botany, Jahangirnagar University, Savar, Dhaka and Principal Scientific Officer, Plant Pathology Division, BARI, Joydebpur, Gazipur 1701, ${ }^{2}$ Professor, Department of Botany, Jahangirnagar University, Savar, Dhaka, ${ }^{3}$ Professor, Department of Plant Pathology, BSMRAU, Gazipur 1706, Bangladesh.
} 
death after 3 weeks. Tinline and Ledingham (1979) reported yield reduction of 2.5-5.6\% depending on the cultivar, and Sallans (1948) estimated that common root rot can decrease yield as much as $17.8 \%$. Hermann and Weise (1985) estimated 50\% yield reduction of wheat due to foot and root rot.

So it should be the first and foremost duty to find out an appropriate control measure of seedling diseases (Foot and root rot and seedling blight) of wheat. Various methods are available for the control of seedling diseases of wheat. Development of resistant variety is one of the cheapest, safest and durable method for the control of seedling diseases of wheat. Many scientists of the world worked on the development of resistant varieties of wheat against seedling diseases through screening (Anaso et al., 1984; Kulkarni et al., 1978; Corrazza et al., 1987; Jalaluddin and Anwar 1989; Ahmed and Bakar 1991; Mishra et al., 1992; Harlapur et al., 1993). But reports on the development of resistant/tolerant variety against seedling diseases of wheat is scanty in the country. Therefore, the present piece of screening work was undertaken to find out any resistant/tolerant variety against major seedling diseases of wheat.

\section{Materials and Method}

\section{Selection of wheat germplasm}

A total of 15 germplasm of wheat, namely BAW-1033, BAW-1045, BAW1056, BAW-1061, BAW-1064, BAW-1004, BAW-1008, BAW-1027, BAW1035, Sonalika, Gourob, Protiva, Shatabdi, Sourov and Kanchan (check) were evaluated under pot culture conditions for their susceptibility to different seedling diseases recorded during the survey in wheat fields.

\section{Site, duration and establishment of experiment}

The experiment was started with 15 germplasrn of wheat during 2003-2004 growing season and was repeated during 2004-2005 crop seasons using nine germplasm. The earthen pots of $30 \mathrm{~cm}$ diameter were filled with sandy loam soil. Before potting, the soil was steam sterilized and mixed with well decomposed cowdung@10 t/ha and Urea, TSP. MP, and Gypsum @ 220, 132, 68 and 125 $\mathrm{kg} / \mathrm{ha}$, respectively (Ahmed and Meisner, 1996).

\section{Preparation of inocula and inoculation of soil}

Inocula of S. rolfsii, B. sorokiniana, and F. oxysporum were prepared on barley grains. The barley grains were soaked in water for 24 hours, excess water was decanted from the grains and poured into $500 \mathrm{ml}$ conical flasks (about $2 / 3^{\text {rd }}$ of the flask). The mouth of conical flask was wrapped with aluminum foil and autoclaved for sterilization at $121{ }^{\circ} \mathrm{C}$ for 15 minutes at $0.7 \mathrm{~kg} / \mathrm{cm}^{2}$ pressure. After proper cooling, the sterilized barley grains were inoculated with 10 mycelial 
blocks ( $0.5 \mathrm{~mm}$ diameter) cut from 5 days old PDA culture in petridishes. Inocula of $R$. solani and $P$. aphanidermatum were prepared in a mixture of sand : maize meal: water. For multiplication of $R$. solani, the mixture composed of $20 \mathrm{~g}$ maize meal: $980 \mathrm{~g}$ sand: $250 \mathrm{ml}$ sterilized water and for $P$. aphanidermatum maize meal: sand:water were mixed at 3:1:1 ratio. The mixtures were sterilized in autoclave at $121{ }^{\circ} \mathrm{C}$ for 15 minuites at $0.7 \mathrm{~kg} / \mathrm{cm}^{2}$, poured into conical flasks and inoculated with 5 days old mycelial blocks of the fungi. The inoculated flasks were kept under room temperature for 3 weeks for growth of the fungus. For uniform colonization, the flasks were shaken with hand every alternate day. The colonized barley grains were air dried on paper trays at room temperature $\left(28^{\circ} \mathrm{C}\right.$ $\pm 2{ }^{\circ} \mathrm{C}$ ) and stored at $4^{\circ} \mathrm{C}$ in a refrigerator for future use.

\section{Soil inoculation}

The pot soil was inoculated with S. rolfsii, B. sorokiniana, F. oxysporum, P. aphanidermatum and $R$. solani before 7 days of sowing. The inoculum was mixed at the rate of $100 \mathrm{~g} / \mathrm{kg}$ of soil. Steam sterilized pot soil was mixed thoroughly with the inocula. After inoculation, the pot soil was covered with sterile sand to ensure the viability of inoculum. Then water the pots from the top to facilitate rapid spread of the inoculum. In case of Pythium, soil was saturated with water before and after the inoculum was added. After inoculation, pots were incubated for 72 hours, first at a temperature suitable for sporangia formation and then suitable for disease development. To avoid the pre- emergence damping off, the inoculum was placed 2-3 cm below the seed (Dingra and Sinclair, 1995).

\section{Layout and design of the experiment}

The pots were arranged on the pot yard of Plant Pathology Division, BARI, Gazipur following completely randomized design. Three pots (replications) were used for each germplasm. Equal number of 25 seeds were sown in each pot. After emergence, watering and mulching were done as and when necessary to maintain appropriate soil condition for proper growth of wheat seedlings.

\section{Data collection}

After emergence, data on total number of healthy and diseased seedlings in each pot were recorded at every 3 days and continued upto 35 days. Finally percent of diseased seedling was calculated based on total number of seedlings per pot. The wheat germplasm were graded according to their reaction to different seedling diseases following a standard grading scale (Anon., 1985). where Resistant (R) = $0-5 \%$, Moderately resistant $(\mathrm{MR})=6-10 \%$, Moderately susceptible $(\mathrm{MS})=11-$ $20 \%$, Susceptible (S) $21-30 \%$ seedlings were diseased. Germplasm showing $31 \%$ or more seedlings diseased were graded as Highly Susceptible (HS). Vigour index (VI) of seedling was determined by using a standard formula (Baki and Anderson, 1972) as followes: 
Vigour Index $=$ (mean root length + mean shoot length $)$ x percent emergence .

All data were analyzed statistically following SPSS programme.

\section{Results and Discussion}

\section{A. Screening test of 2002-2003}

Germination of different wheat germplasm varied from 56 to $96 \%$ with a mean of 77.33\% and standard deviation 12.344\%. The highest percent of seedling germination was recorded in Shatabdi followed by BAW-1035 and BAW-1004 showing 92\% germination. Seed germination in rest of the germplasm ranged 5688\% (Table 1).

Table 1. Response of 15 wheat germplasms to seedling disease (\%) and other agronomic characters during 2002-03.

\begin{tabular}{|c|c|c|c|c|c|c|c|c|}
\hline $\begin{array}{c}\text { Wheat } \\
\text { germplasm }\end{array}$ & $\begin{array}{l}\text { Germinati } \\
\text {-on (\%) }\end{array}$ & $\begin{array}{c}\text { Seedling } \\
\text { population } \\
\text { per pot }\end{array}$ & $\begin{array}{c}\text { Pre- } \\
\text { emerga- } \\
\text { nce death } \\
(\%)\end{array}$ & $\begin{array}{c}\text { Diseased } \\
\text { seedling } \\
(\%)\end{array}$ & \begin{tabular}{|c} 
Shoot \\
length \\
$(\mathrm{cm})$
\end{tabular} & $\begin{array}{c}\text { Root } \\
\text { length } \\
(\mathrm{cm})\end{array}$ & $\begin{array}{l}\text { Vigour } \\
\text { index }\end{array}$ & Grading \\
\hline BAW-1033 & 72 & 18 & 28 & 15.1 & 16.23 & 10.27 & 1893 & MS \\
\hline I3AW-1045 & 88 & 22 & 12 & 8.8 & 17.27 & 11.13 & 2523 & MR \\
\hline BAW-1056 & 60 & 15 & 40 & 12.8 & 15.40 & 9.77 & 1512 & MS \\
\hline BAW-1061 & 84 & 21 & 16 & 9.3 & 19.50 & 12.5 & 2725 & MR \\
\hline BAW -1064 & 68 & 17 & 32 & 13.7 & 15.87 & 10.20 & 1783 & MS \\
\hline BAW-1004 & 92 & 23 & 8 & 8.6 & 18.63 & 12.0 & 2807 & MR \\
\hline BAW -1008 & 80 & 20 & 20 & 9.7 & 17.07 & 10.9 & 2269 & MR \\
\hline BAW -1027 & 56 & 14 & 44 & 14.5 & 15.57 & 9.83 & 1393 & MS \\
\hline BAW -1035 & 92 & 23 & 8 & 8.2 & 18.53 & 12.5 & 2880 & MR \\
\hline Sonalika & 64 & 16 & 36 & 16.5 & 16.47 & 10.63 & 1690 & MS \\
\hline Gourob & 84 & 21 & 16 & 9.3 & 19.53 & 12.60 & 2744 & MR \\
\hline Protiva & 76 & 19 & 24 & 8.6 & 17.20 & 10.73 & 2143 & MR \\
\hline Shatabdi & 96 & 24 & 4 & 6.9 & 18.57 & 12,53 & 2991 & MR \\
\hline Sourov & 68 & 17 & 32 & 9.7 & 19.17 & 12.8 & 2157 & MR \\
\hline Kanchan & 80 & 20 & 20 & 9.6 & 18.23 & 10.8 & 2286 & MR \\
\hline Mean & 77.33 & 9.720 & 22.66 & 10.75 & 17.55 & 11.28 & 2253.06 & \\
\hline $\begin{array}{l}\text { Standard } \\
\text { Deviation }\end{array}$ & 12.344 & 1.644 & 12.344 & 1.464 & 1.431 & 1.096 & 518.25 & \\
\hline
\end{tabular}

Resistant $(R)=0-5 \%$. Moderateiy resistant $(M R)=6-10 \%$, Moderately susceptible $(M S)=11-20 \%$. Susceptible (S)= 2l-30\% and Highly Susceptible (HS)= 31\% or more seedlings disease. 
The seedling population per pot ranged 14-24 with a mean of 9.72 and standard deviation 1.644. The highest number of plant population was recorded in Shatabdi, while the lowest seedling population was found in germplasrn BAW1027 (Table 1).

The pre-emergence mortality ranged $4-40 \%$ with a mean of $22.66 \%$ and standard deviation $12.344 \%$. The lowest percent of pre-erncrgence death was recorded in Shatabdi. The second lowest pre-emergence mortality of $8 \%$ was recorded in BAW-1004 and BAW-1035, which were followed by BAW-1045, BAW-1061 and Gourob showing 12-16\% mortality. The highest pre-emergence mortality was recorded in BAW-1027 followed by BAW-1056 (Table 1).

Percentage of diseased seedling was calculated on the basis of total population of seedlings in a pot. The parameter varied from 6.9 to $16.5 \%$ with mean $10.75 \%$ and standard deviation $1.464 \%$. The lowest percentage of diseased seedling was recorded from Shatabdi and the highest from Sonalika (Table 1). The highest shoot length was found in Gourob followed by that in BAW-1061 and Sourov, while the lowest shoot length of $15.40 \mathrm{~cm}$ was recorded in BAW1056. Among 15 germp $\}$ asrn, mean shoot length ranged $15.40-19.53 \mathrm{~cm}$ with mean $17.55 \mathrm{~cm}$ and standard deviation $1.431 \mathrm{~cm}$ (Table 1$)$.

The range, mean and standard deviation in root length of 15 gerrnplasm were 9.77-12.80, 11.28 and $1.096 \mathrm{~cm}$, respectively. The highest root length was recorded in Sourov followed by Gourob, Shatabdi, BAW-1035, I3AW-1061 and BAW-1004 having root length of $12.00-12.80 \mathrm{~cm}$. The lowest root length was found in BAW- 1056. Vigour index of seedlings varied 1393-2991 with mean 2253 and standard deviation 518.25. The highest vigour Index of seedling was recorded in Shatabdi followed by that in BAW-1035 and BAW-1004, while the lowest vigour index was recorded in BAW-1027 (Table 1).

Out of 15 germplasm, 10 germplasm including Kanchan (check) were graded as moderately resistant (MR) and remaining 5 germplasm gave moderately susceptible (MS) reaction to seedling diseases of wheat. Based on the lower percent of diseased seedling, moderately resistant reaction (MR) and higher vigour index, 9 germplasm of wheat, namely BAW-1045, BAW-1061, BAW1004, BAW-1008, BAW-1035, Gourob, Protiva, Shatabdi and Sourov were selected for further evaluation. In the next year, the selected 9 germplasm were tested under heavy disease pressure to find out some materials tolerant to seedling disease.

\section{B. Screening test of 2003-2004}

Results of the experiment conducted during 2003-2004 are presented in Table 2. Germination ranged $60-96 \%$ with mean $78 \%$ and standard deviation $12.111 \%$. The highest germination was recorded in BAW-1045 (96\%) followed by 
Shatabdi (92\%) and BAW-1035 (88\%). The lowest germination was recorded in germplasm BAW-1008. Seedling population per pot ranged 15-24 with mean 19.5 and standard deviation 3.027. The highest population was recorded in BAW-1045 followed by the variety Shatabdi, BAW-1035, BAW-1004 and Protiva. The lowest population was recorded in BAW-1008 followed by that in BAW-1061 and Kanchan. Pre-emergence mortality ranged 4-40\% with mean $22.0 \%$ and standard deviation $12.110 \%$. The lowest pre-emergence death of seedling was recorded in BAW-1045 followed by Shatabdi. Pre-emergence death of seedling were 12 and 16\% in BAW- 1035 and BAW-1004, respectively. The highest percent of pre-emergence mortality was found in BAW-1008, which was followed by BAW-1061 and Kanchan. The incidence of seedling diseases in 9 wheat germplasm ranged 5.5-15.6\% with mean $10.21 \%$ and standard deviation $2.663 \%$. The lowest percent of diseased seedling was recorded in BAW- 1045 followed by that of Shatabdi. Incidence of diseased seedling were recorded as 6.3 and 6.5\%, respectively, in BAW-1004 and Protiva. The highest incidence of diseased seedling was found in BAW- 1008.

Table 2. Response of 9 wheat germplasms to seedling disease (\%) and agronomic characters during 2003-2004.

\begin{tabular}{l|l|l|l|l|c|c|c|c}
\hline $\begin{array}{c}\text { Wheat } \\
\text { germplasm }\end{array}$ & $\begin{array}{c}\text { Germinati- } \\
\text { on (\%) }\end{array}$ & $\begin{array}{c}\text { Seedling } \\
\text { population/ } \\
\text { pot }\end{array}$ & $\begin{array}{c}\text { Pre- } \\
\text { emerga-nce } \\
\text { death }(\%)\end{array}$ & $\begin{array}{c}\text { Diseased } \\
\text { seedling } \\
(\%)\end{array}$ & $\begin{array}{c}\text { Shoot } \\
\text { length } \\
(\mathrm{cm})\end{array}$ & $\begin{array}{c}\text { Root } \\
\text { length } \\
(\mathrm{cm})\end{array}$ & $\begin{array}{c}\text { Vigour } \\
\text { index }\end{array}$ & Grading \\
\hline BAW-1045 & 96 & 24 & 4 & 5.5 & 18.47 & 11.23 & 2835 & R \\
BAW-1061 & 64 & 16 & 36 & 12.4 & 16.20 & 10.07 & 1687 & MS \\
BAW-1035 & 88 & 22 & 12 & 13.7 & 14.07 & 8.3 & 1944 & MS \\
BAW-1008 & 60 & 15 & 40 & 15.6 & 15.40 & 9.57 & 1505 & MS \\
BAW-1004 & 84 & 21 & 16 & 6.3 & 17.50 & 10.47 & 2373 & MR \\
Gourob & 72 & 18 & 28 & 12.9 & 15.23 & 9.77 & 1776 & MS \\
Protiva & 80 & 20 & 20 & 6.5 & 18.10 & 11.37 & 2294 & MR \\
Shatabdi & 92 & 23 & 8 & 5.7 & 19.27 & 12.17 & 2872 & R \\
Sourov & 76 & 19 & 24 & 12.2 & 16.07 & 10.27 & 2049 & MS \\
Kanchan & 68 & 17 & 32 & 11.3 & 17.43 & 11.40 & 1941 & MS \\
\hline Mean & 78 & 19.5 & 22.0 & 10.21 & 16.77 & 10.46 & 2127.6 & \\
Standard & 12.111 & 3.027 & 12.110 & 2.663 & 1.641 & 1.123 & 462.19 & \\
deviation & & & & & & & & \\
\hline
\end{tabular}

Resistant $(\mathrm{R})=0-5 \%$, Moderately resistant $(\mathrm{MR})=6-10 \%$. Moderately Susceptible (MS) $11-20 \%$, Susceptible $(S)=21-30 \%$ and Highly Susceptible $(\mathrm{HS})=31 \%$ or more seedlings disease. 
Among 9 germplasm, minimum shoot length of wheat seedling was $14.07 \mathrm{~cm}$ and the maximum was $19.27 \mathrm{~cm}$ with a mean $16.77 \mathrm{~cm}$ and standard deviation 1.641. Germplasm BAW-1035 had shortest shoot and Shatabdi had the longest shoot. Usually the healthy seedling was longer than the diseased seedling. Therefore, the highest length of shoot was recorded in Shatabdi where lower percent of diseased seedling (5.7\%) was recorded. The length of shoot was $18.47 \mathrm{~cm}$ in BAW-1045 where incidence of diseased seedling was 5.5\%. The lowest length of shoot was found in BAW-1035 where percent of diseased seedling was $13.7 \%$.

Root length varied from 8.30 to $12.17 \mathrm{~cm}$ with mean 10.46 and standard deviation 1.123. The longest root was also found in Shatabdi where percent of diseased seedling was recorded as $5.7 \%$, and the shortest root was found in BAW-1035, where incidence of diseased seedling was $13.7 \%$. Highest seedling Vigour index of 2872 was found in Shatabdi where percent of diseased seedling was recorded as $5.7 \%$. Second highest Vigour Index of seedling was recorded in BAW-1045 where incidence of diseased seedling was only 5.5\%.

During 2003-2004 crop season, out of 9 germplasrn, BAW-1061, BAW1035, BAW-1008, Gourob, Sourob and Kanchan were graded as moderately susceptible (MS), 2 germplasm, BAW-1004 and Protiva were moderately resistant (MR) and remaining 2 germplasm namely BAW-1045 and Shatabdi gave resistant $(\mathrm{R})$ reaction to seedling diseases of wheat.

Considering the lower percent of diseased seedling, resistant /moderately resistant reaction, and higher vigour index, four wheat gerrnplasm, namely Shatabdi, BAW-1045, BAW-1004 and Protiva were finally selected as tolerant materials against seedling diseases of wheat.

Many scientists of the world screened wheat germplasms for their resistance/susceptibility against seedling diseases (Anaso et al. 1984; Karaw and Sing, 1975; Kulkarni et al., 1978; Ahmed and Bakr, 1991; Mishra et al., 1992).

Anaso et al. (1984) tested 14 cultivars against foot and root rot in pot soil. All 14 cultivars, showed mild to moderate susceptibility to Drechslera spp. and Fusarium spp. None of them was immune or highly susceptible. Karaw and Singh (1975) tested 15 wheat varities against $P$. graminicolum, $H$. sativum, $S$. rolfsii and Fusarium spp. All of them were graded as susceptible. Kulkarni et al. (1978) tested 35 wheat varieties against S. rolfsii and identified 4 materials as resistant. Ahmed and Bakr (1991) identified only 9 wheat gerrnplasm as resistant to $S$. rolfsii, out of 140 germplasm tested under inoculated condition. In India, 71 wheat varieties were evaluated for resistant to S. rolfrii and graded as resistant and susceptible of different degress (Mishra et al., 1992). 


\section{References}

Ahmed, F. and M.A. Bakr 1991. Screening for resistance to foot and root rot of wheat. Bangladesh J. Plant Pathol. 7: (1-2): 35

Ahmed, H.U. 1986. Prevailing Wheat Diseases in Bangladesh. In: Third National Wheat Training Workshop (Edt. Anonymous). Wheat Research Centre, BARI, Joydebpur, Gazipur. 124-134 pp.

Ahmed, H.U. 1994. Diseases of crops and its impact on crop production. In: Proc. PABGIFAP Asia Working Group Meeting, Dhaka, 3-5 May, 1994. 36-42 pp.

Ahmed, H.U. and M.M. Hossain. 1985. Crop Diseases Survey and Establishment of a Herbarium at BARI. Plant Pathology Division, BARI, Joydebpur, Gazipur. 107 p.

Ahmed, S.M. and C.A. Meisner, 1996. Wheat Research and Development in Bangladesh. Bangladesh Australia Wheat Improvement Project and CIMMYT- Bangladesh. 201 pp.

Alam, K.B., M.A. Shaheed, A.U. Ahmed and P.K. Malaker. 1994. Bipolaris leaf blight (spot blotch) of wheat in Bangladesh. In: Wheat in Heat-stressed Environments: Irrigated, Dry Areas and Rice-Wheat Farming Systems (Edts D.A. Saunders and G.P. Hettel), Mexico, D.F. CIMMYT. 339-342 pp.

Anaso, A.B., P. D. Tyagi and A.M. Emechebe, 1984. Preliminary evaluation of resistance in wheat to foot rot and root rot caused by Drechslera rostrata and Fusarium equiseti and pathogenic behaviour of different isolates of the pathogens on wheat cultivar Pitic 62. Samaru J. of Agric. Res. 2(1-2): 33-37.

Anomymous. 1985, Annual Report (1984-85), Plant Pathology Division, BARI, Joydebpur, Gazipur.

Baki, A.A. and J.D. Anderson. 1972. Physiological and biological deterioration of seeds. in: Seed Biology, Vol. 11, Academic Press, New York, 283-315 pp.

Corrazza, L., B. Balmas, and G. Chilosi. 1987. Foot rot in durun wheat. Informatore Agario. 43: 38

Chattopadhay, S.B. 1953. Root rot and foot rot of wheat caused by Scierotium roifsii Sacc. and Curvularia specilera (bain) Boed - Helm inthosporium letramera Mcknney, Sci. Cult. 19: 101-2

Dhingra D. Onkar and James B. Sinclair. 1986. Basic Plant Pathology Methods. CRC Press, inc. Boca Raton, Florida. 355 p.

Harlapur, S. I., Srikant Kulkarni. R.K. Hegde. V.B. Nargund and S. Kulkarni. 1993. Wheat genotypes against foot rot. Current Research, University of Agricultural Sciences, Bangalore. 22(2): 33-34.

Hermann, T. and M.V. Wiese. 1985. Influence of cultural practices on the incidence of foot rot in winter wheat. Plant Disease 69(11): 948-950.

Jalaluddin, M. and Q. M. K Anwar. 1989. Reaction of wheat varieties to foot rot and root rot disease of wheat in Pakistan. Pakistan J. of Bot. 21(1): 191-194.

Karaw, L.P. and R.S. Sing. 1975. Studies on the root rot complex of wheat in India. 1. Varietal reaction. Indian J. Mycol. P1. Pathol. 5: 96 - 97. 
Kulkarni, S., A. L. Siddaramaiah, K.S.K. Prasad, Srikant Kulkarni and K.S. Krishna Prasad. 1978. Varietal resistance of promising wheat cultivars to foot rot disease. Current Research 7(12): 208-209.

Mishra, P.C, R.K. Pathak and S.K. Jain. 1992. Incidence of foot rot disease in wheat in Sagar region. JNKVV Res. J. 26(2): 80

Sallans, B.J. 1948. Inter- relations of common root and other factors with wheat yields in Saskatchewan. Sci. Agric. 28: 6-21.

Talukdar, M.J. 1974. Plant diseases in Bangladesh. Bangladesh J. Agril. Res. 1(1): 61-86.

Tinline R.D., R.J. Ledingham. 1979. Yield losses in wheat and barley cultivars from common root rot in field tests. Can. J. Plant Sci. 59: 313-320. 